\title{
Viruses that affect Apis mellifera and their occurrence in Brazil
}

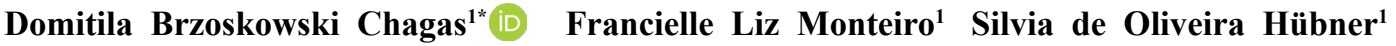 Marcelo de Lima $^{1}$ Geferson Fischer ${ }^{1}$}

${ }^{1}$ Programa de Pós-graduação em Veterinária, Faculdade de Veterinária, Universidade Federal de Pelotas (UFPel), 96010-900, Pelotas, RS, Brasil. E-mail: chagas.domitila@gmail.com. "Corresponding author.

ABSTRACT: Bees are very important insects for agriculture, fulfilling an important role in pollination and renewal of the ecosystem. However in several countries significant losses of colonies and population decline of honeybees and native bees have been reported in recent years. Most researchers reported that premature losses are linked to several factors, including viruses that have a great impact on the colonies. This article reports the identification of new viruses, some transmission routes, the association of these parasites with the symptoms of the diseases that affect the health of honeybees, as well as viruses that have been described in Brazil.

Key words: Africanized bees, pollinating insects, diseases, sanity.

Vírus que acometem Apis mellifera e sua ocorrência no Brasil

RESUMO: As abelhas são insetos de grande importância na agricultura, cumprindo um papel muito importante na polinização e na renovação do ecossistema. No entanto, em diversos países têm sido relatadas perdas significativas de colônias e declínio da população de abelhas meliferas e nativas, nos últimos anos. Com isso, surgiram novos estudos sobre este assunto. A maioria dos pesquisadores relata que as perdas prematuras estão ligadas a diversos fatores, dentre eles os vírus, que causam grande impacto nas colônias. Este artigo visa expor as novas identificações de vírus, algumas rotas de transmissão, a associação dos mesmos a parasitas e a sintomatologia das enfermidades que afetam a saúde de abelhas meliferas, bem como os vírus que já foram descritos no Brasil.

Palavras-chave: abelhas africanizadas, insetos polinizadores, doenças, sanidade.

\section{INTRODUCTION}

Bees are important pollinators that are essential for agricultural production (PETTIS, 2013; DeGRANDI-HOFFMAN \& CHEN, 2015; MCMENAMIN \& FLENNIKEN, 2018). Of all food produced globally, $35 \%$ is dependent on pollination resulting from biological factors, and $90 \%$ involves Apis mellifera as pollinators (GENERSCH, 2010). In Brazil, 85 cultivars of 141 species used for biodiesel and human and animal consumption depend to some extent on animal pollination (GIANNINI et al., 2015). Despite the importance of bees in global food production in the United States, Japan, and several countries in Europe and Latin America, extensive loss of colonies and population decline of native bees have been described in recent years (NEUMANN \& CARRECK, 2010; VANDAME \& PALACIO, 2010). The use of pesticides (PETTIS, 2013; COULON et al., 2018; NAZZI \& PENNACCHIO, 2018), the geographic location of the colonies, unfavorable environmental factors including the lack of shade in hot regions and lack of a supply of water of sufficient quality, inadequate dietary supplementation and unbalanced diets, physiological and behavioral changes including disorientation and reduction of foraging and posture (PIRES et al., 2016; CATAE, 2016; MOLINERI et al., 2017), immunological activities (DeGRANDI-HOFFMAN \& CHEN, 2015), and different types of pathogens, may contribute to these losses (NAZZI \& PENNACCHIO, 2018).

Notably, viruses are the pathogens that contribute the most to the decrease in the health and the number of bee colonies globally. To date, approximately 24 species of virus have been identified in bees (BAILEY \& BALL, 1991; De MIRANDA et al., 2013; REMNANT, 2017). Prevalence and distribution of these viruses have been associated 
with, among others, the establishment of the Varroa destructor mite. This ectoparasite acts as a transmission vector for different types of viruses, and its establishment in bee colonies has contributed to the increase in the virulence of some species, such as the Acute bee paralysis virus (ABPV) and the Deformed wing virus (DWV) (MOLINERI et al, 2017; REMANT, 2017; SANTAMARIA et al., 2018).

The foregoing highlighted that several factors are linked to the premature loss of bees, which detrimentally affects the colonies. Monitoring and further studies are critical to better understand these variables and to develop infection prevention strategies. This review provided an overview of the current knowledge of virus identification in Brazil as well as worldwide, together with some factors associated with transmission that affect the health and immunity of honeybees.

\section{Apiculture}

There are 28 known subspecies of $A$. mellifera. In Brazil, the introduction of subspecies allowed the emergence of Africanized bees, which are poly-hybrids of the subspecies of European $A$. mellifera mellifera and A. mellifera ligustica and of the African subspecies $A$. mellifera scutellate bees (VANDAME et al., 2002). Moreover, throughout the Brazilian territory there is a diversity of non-stinging native bees that are pollinators and producers of honey. About 250 species of these native bees belonging to the Meliponini tribe have been described in Brazil (MESSAGE et al, 2012) and are susceptible to diseases caused by viruses (GENERSCH et al., 2006; MESSAGE et al, 2012; SANTAMARIA et al., 2018). Therefore, the study of agents, including viruses, is very important, especially concerning transmission routes and signs of diseases that affect the health of honey bees, which are responsible for the renewal and conservation of the ecosystem.

\section{Viruses that affect bees}

Viruses are being intensively studied for their impact on the health of bees and because of the extensive apiculture losses occurring worldwide, which are influenced by biotic and abiotic factors, including the synergistic negative effects of multiple pathogen co-infection and/or pesticide exposure (PETTIS, 2013; COULON et al., 2018). The great majority of the viruses that have already been isolated and characterized in bees are classified as positivestrand RNA viruses within the order Picornavirales, comprising the families Dicistroviridae and Iflaviridae. Prominent viruses include ABPV, DWV,
Black queen cell virus (BQCV), Sacbrood bee virus (SBV), Kashmir bee virus (KSV), and Israeli acute bee paralysis (IAPV). To date, only one doublestranded DNA virus, A. mellifera filamentous virus (AmFV) (BAILEY \& BALL, 1991; De MIRANDA, 2010; McMENAMIN \& GENERSCH, 2015), has been identified. Viruses of the order Rhabdovirus, Apis mellifera rhabdovirus-1 (ARV-1) and Apis mellifera rhabdovirus-2 (ARV-2) were identified (REMNANT et al., 2017).

The signs of diseases are the main and fastest means of diagnosis of these diseases in the apiary. Some of these diseases do not present visible symptoms, do not have similar symptoms to each other, or are not present in all life stages of bees (De MIRANDA et al., 2015, McMAHON et al., 2018). However, according to De MIRANDA et al. (2015), there are viruses that induce symptoms when present in high titers and that persist naturally in hives at low levels with no apparent clinical signs using a variety of transmission routes. There are also asymptomatic viruses that, at low levels of infection, shorten life time of bees. The following are the main viruses that affect bees, as well as their occurrence in Brazil. Other viruses are summarized in tables 1 and 2 .

\section{Deformed wing virus (DWV)}

The DWV is widely distributed in honey bees, being associated worldwide with colony collapse, especially when vectored by $V$. destructor (MOLINERI et al., 2017; YUE \& GENERSCH, 2015). The virus becomes symptomatic due to the stress resulting from the parasitism of the mite, which destabilizes the host immune system (SHEN et al., 2005; RIBIÈRE et al., 2008; AMOSCIA et al., 2018). Symptoms of the virus consist of the appearance of wrinkled wings in infected bees. In addition, swollen abdomen and malformed body are characteristic symptoms (BAILEY \& BALL, 1991; De MIRANDA et al., 2013). The DWV can remain asymptomatic at all stages of life of the colonies in the absence of the mite (CHEN et al., 2006). Bee viruses are transmitted vertically within the species (progeny infection through the transovarian route in the queen and the semen of the hornets) (CHEN et al., 2006; De MIRANDA \& GENERSCH, 2010; YUE \& GENERSH, 2015) and horizontally (glandular secretions used to feed larvae and queens, food contamination) both within species and among different genera of bees (FORFEET et al., 2016; NAZZI \& PENNECY, 2018). Concerning vertical transmission, CHEN et al. (2006) reported that bees showed the presence of BQCV and DWV viruses, 
Table 1 - Summary of physical properties (particle shape, size, type of genome, the taxonomy and symptoms) of 8 viruses related to bees.

\begin{tabular}{|c|c|c|c|c|c|c|c|}
\hline --------------Virus---- & --------- & Form & Size & Nucleic acid & Taxonomy & Symptomatology & References \\
\hline $\begin{array}{l}\text { Apis mellifera } \\
\text { filamentous virus }\end{array}$ & AmFV & filament & $150 \mathrm{~nm} \times 450$ & dsDNA & $\begin{array}{l}\text { Baculoviri } \\
\text { dae }\end{array}$ & $\begin{array}{l}\text { No physical symptoms } \\
\text { Becomes white and milky } \\
\text { hemolymph }\end{array}$ & $\begin{array}{l}\text { BAILEY \& } \\
\text { BALL, } 1991\end{array}$ \\
\hline $\begin{array}{l}\text { Apis iridescente } \\
\text { virus }\end{array}$ & AIV & polyhedral & $150 \mathrm{~nm}$ & dsDNA & $\begin{array}{c}\text { Iridovirida } \\
e\end{array}$ & $\begin{array}{c}\text { Symptoms like CBPV Only } \\
\text { known to occur in adult } \\
\text { bees }\end{array}$ & $\begin{array}{l}\text { BAILEY \& } \\
\text { BALL, } 1991\end{array}$ \\
\hline $\begin{array}{l}\text { Arkansas bee } \\
\text { virus / Berkeley } \\
\text { bee Picorna-like } \\
\text { virus }\end{array}$ & $\begin{array}{l}\text { ABV / } \\
\text { BBPV }\end{array}$ & icosahedral & $30 \mathrm{~nm}$ & ssRNA & $?$ & $\begin{array}{l}\text { No known symptoms in } \\
\text { adult bees and pupae }\end{array}$ & $\begin{array}{l}\text { BAILEY \& } \\
\text { BALL, } 1991\end{array}$ \\
\hline Bee virus $X$ & BVX & icosahedral & $35 \mathrm{~nm}$ & ssRNA & $?$ & $\begin{array}{c}\text { Does not multiply in larvae } \\
\text { and pupae Associated with } \\
\text { the protozoan } \\
\text { Malpighamoebamellificae }\end{array}$ & $\begin{array}{l}\text { BAILEY \& } \\
\text { BALL, } 1991\end{array}$ \\
\hline Bee virus $Y$ & BVY & icosahedral & $35 \mathrm{~nm}$ & ssRNA & $?$ & $\begin{array}{l}\text { Serologically related to } \\
\text { BVX without symptoms in } \\
\text { adult bees, pupae and larvae } \\
\text { Associated with N.apisin } \\
\text { adult bees }\end{array}$ & $\begin{array}{l}\text { BAILEY \& } \\
\text { BALL, } 1991\end{array}$ \\
\hline Wing virus Clody & CWV & icosahedral & $17 \mathrm{~nm}$ & ssRNA & $?$ & $\begin{array}{c}\text { Opaque wings of adult bees, } \\
\text { do not propagate in larvae } \\
\text { and pupae } \\
\text { Already detected in } \\
\text { Africanized bees in Brazil }\end{array}$ & $\begin{array}{l}\text { BAILEY \& } \\
\text { BALL, } 1991\end{array}$ \\
\hline Egypt bee virus & EBV & icosahedral & $30 \mathrm{~nm}$ & ssRNA & Iflaviridae & $\begin{array}{c}\text { Serologically related to } \\
\text { DWV, but has no } \\
\text { known symptoms in adults, } \\
\text { pupae and larvae }\end{array}$ & $\begin{array}{l}\text { BAILEY et } \\
\text { al., } 1979\end{array}$ \\
\hline $\begin{array}{l}\text { Slow bee } \\
\text { paralysis virus }\end{array}$ & SBPV & icosahedral & $30 \mathrm{~nm}$ & ssRNA & Iflaviridae & $\begin{array}{l}\text { Paralysis of two pairs of } \\
\text { front legs in adult bees } \\
\text { Associated with V. } \\
\text { destructor } \\
\text { No visible symptoms in } \\
\text { pupae and larvae }\end{array}$ & $\begin{array}{l}\text { BAILEY \& } \\
\text { BALL, } \\
\text { 1991; DE } \\
\text { MIRANDA } \\
\text { et al., } 2010\end{array}$ \\
\hline
\end{tabular}

Information in the table has been adapted from Bailey \& Ball, 1991; Miranda et al, 2013; McMenamin \& Flennken, 2018. ds:double-stand; ss:single-strand.

the same two viruses were detected in their eggs, and in larvae and adult worker bees, demonstrating that there may be transmission of the queen to its progeny.

Originally, the virus was identified in European bees. However, it can cause infections in various other species of bees, such as A. cerana, A. dorsata, and A. florea (ZHANG et al., 2012), Bombus terrestris and B. pascuorum in Germany (GENERSCH et al., 2006), B. atratus in Argentina (REYNALDI et al., 2013), Ceratina smaragdula, in Hawaii (SANTAMARIA et al., 2018), and in wasps (GENERSCH et al., 2006; LEVITT et al, 2013; SANTAMARIA et al., 2018). Among these species, some are present in Brazil, such as B. atratus and $B$. terrestris, showing the importance of the study of viruses and co-infection in other pollinating insects. The DMV has been detected, along with other viruses (APV, BQCV, and IAPV) in honeybees in Brazil using the double immunodiffusion technique (MESSAGE et al. 2012). The DWV includes two closely related strains: $V$. destructor virus-1 (VDV1) and the Kakugovirus (KV) (De MIRANDA \& GENERSH, 2010).

\section{Black queen cell virus (BQCV)}

Originally, BQCV was isolated in samples of decomposed queens with black spots, giving it the name of "black queen" (BAILEY \& BALL, 
Table 2 - Summary of physical properties (particle shape, size, type of genome, the taxonomy and symptoms) of newly discovered viruses related to bees.

\begin{tabular}{|c|c|c|c|c|c|c|}
\hline ------------Virus---- & -------- & Form and Size & Nucleic acid & Taxonomy & Symptomatology & References \\
\hline $\begin{array}{l}\text { Apis mellifera } \\
\text { flavivirus }\end{array}$ & AFV & $\begin{array}{l}\text { icosahedral } \\
\text { Approximately } \\
60 \mathrm{~nm}\end{array}$ & ssRNA & Flaviviridae & Symptoms known to date & $\begin{array}{l}\text { REMNANT et } \\
\text { al., } 2017\end{array}$ \\
\hline $\begin{array}{l}\text { Api smellifera - } \\
\text { Bunyaviruses } 1 \\
\text { and } 2\end{array}$ & $\begin{array}{l}\text { ABV-1; } \\
\text { ABV-2 }\end{array}$ & $?$ & ssRNA & Bunyaviridae & Symptoms unknown & $\begin{array}{l}\text { REMNANT et } \\
\text { al., } 2017\end{array}$ \\
\hline $\begin{array}{l}\text { Apis mellifera } 1 \\
\text { and } 2, \text { rhabdovirus }\end{array}$ & ARV & $?$ & ssRNA & Rhabdoviridae & $\begin{array}{l}\text { Rhabdoviridae are transmitted } \\
\text { by arthropods }\end{array}$ & $\begin{array}{l}\text { LEVIN et al., } \\
\text { 2017.; } \\
\text { REMNANT et } \\
\text { al., } 2017\end{array}$ \\
\hline $\begin{array}{l}\text { Aphid lethal } \\
\text { paralysis virus }\end{array}$ & ALPV & $\begin{array}{l}\text { Icosahedral } \\
30 \mathrm{~nm}\end{array}$ & ssRNA & Dicistroviridae & $\begin{array}{l}\text { Virus of aphids and agricultural } \\
\text { pests Detected in adult bees, } \\
\text { during the decrease of pollen }\end{array}$ & $\begin{array}{l}\text { RUNCKEL et } \\
\text { al., } 2011\end{array}$ \\
\hline $\begin{array}{l}\text { Big River virus } \\
\text { Sioux }\end{array}$ & BSRV & $\begin{array}{l}\text { Icosahedral } \\
30 \mathrm{~nm}\end{array}$ & ssRNA & Dicistroviridae & $\begin{array}{l}\text { Closely related to } \\
\text { Rhopalosiphumpadi virus, } \\
\text { found in aphids }\end{array}$ & $\begin{array}{l}\text { RUNCKEL et } \\
\text { al., } 2011\end{array}$ \\
\hline $\begin{array}{l}\text { Halictus scabiosae } \\
\text { Adlikon virus }\end{array}$ & HsAV & $?$ & ssRNA & $?$ & Related to Lake Sinai virus & $\begin{array}{l}\text { BIGOT et al., } \\
2017\end{array}$ \\
\hline $\begin{array}{l}\text { Lake Sinai Virus- } 1 \\
\text { and } 2\end{array}$ & $\begin{array}{r}\text { LSV-1 } \\
\text { / LSL-2 }\end{array}$ & $?$ & ssRNA & $?$ & $\begin{array}{l}\text { No visible symptom. } \\
\text { Positive correlation with } \\
\text { Nosema LSV-2 has higher } \\
\text { incidence in late winter }\end{array}$ & $\begin{array}{l}\text { RUNCKELl } \\
\text { et al., } 2011\end{array}$ \\
\hline Moku virus & MV & $\begin{array}{l}\text { Icosahedral } \\
\text { Approx. } \\
30 \mathrm{~nm}\end{array}$ & ssRNA & Iflaviridae & $\begin{array}{c}\text { Discovered in the wasp, } \\
\text { (Vespulapensylvanica) and } \\
\text { phylogenetically related to } \\
\text { SBPV }\end{array}$ & $\begin{array}{l}\text { MORDECAI } \\
\text { et al., } 2016\end{array}$ \\
\hline \multirow{3}{*}{$\begin{array}{l}\text { Tobacco ringspot } \\
\text { virus }\end{array}$} & \multirow{3}{*}{ TRSV } & \multirow{3}{*}{$\begin{array}{l}\text { icosahedral } \\
25 \text { to } 30 \mathrm{~nm}\end{array}$} & \multirow{3}{*}{ ssRNA } & \multirow{3}{*}{ Secoviridae } & Originally from plants & \multirow{3}{*}{ LI et al., 2014} \\
\hline & & & & & $\begin{array}{l}\text { Discovered in bees and } \\
\text { replicates in different parts of } \\
\text { the body }\end{array}$ & \\
\hline & & & & & $\begin{array}{l}\text { Varroahas been detected and is } \\
\text { possible spreader of virus }\end{array}$ & \\
\hline
\end{tabular}

Information in the table has been adapted from Bailey \& Ball, 1991; Miranda et al., 2013; McMenamin \& Flennken, 2018. ds:doublestand; ss:single-strand.

1991). At the initial stage of infection, ill larvae have a yellow appearance and a hard and rough baglike tegument, which are clinical signs of the virus (BAILEY \& BALL, 1991). The virus is present in adult bees without apparent symptoms (BAILEY \& BALL, 1991; De MIRANDA et al., 2013). It is widely associated with the parasite Nosema apis, both in nature and in the laboratory (BAILEY \& BALL, 1991). Even without knowledge of the relationship between the virus and the parasite, it has been reported that the BQCV levels rise in bees infected with the parasite (BAILEY \& BALL, 1991; RIBIÈRE et al., 2008). The BQCV as well as DWV that were originally reported in European bees have already been described in multiple host species, such as
Hymenoptera. In addition, there is evidence of active infection in B. huntii species in the United States and Germany (PENG et al., 2011; SINGH et al., 2010; RADZEVIČIŪTÉ et al, 2017), B. atratus in Argentina (REYNALDI et al., 2013), and in Africanized bees in Brazil (TEIXEIRA et al., 2008a). The presence of the virus in the pollen of forage bees of $A$. mellifera has been reported, indicating the dynamic capacity of the virus (PENG et al., 2011; SINGH et al., 2010; ZHANG et al., 2012).

Acute bee paralysis virus (ABPV), Israeli acute bee paralysis (IAPV) and Kashmir bee virus (KSV)

The ABPV, IAPV, and KSV viruses are part of a closely related virus complex, the Dicistroviridae 
family, and are considered virulent and widely distributed in $A$. mellifera. They characteristically kill both the pupae and adult bees very quickly, from 3 to 5 days after inoculation (BAILEY \& BALL, 1991). The ABPV was intentionally discovered as a by-product during virus transmission studies of chronic paralysis (CBPV). It was identified because honeybees died earlier than the bees infected with CBPV (BAILEY \& BALL., 1991; RIBIERE et al, 2010; MIRANDA et al, 2010). Subsequently, ABPV was detected in the thoracic salivary glands of adult bees, which transmitted the virus to the larvae during feeding (BAILEY \& BALL, 1991).

$\mathrm{KBV}$ was discovered as a contaminant in Apis iridescent virus and $A$. cerana samples, multiplied in high titers in A. mellifera (BAILEY \& BALL, 1991; RIBIERE et al., 2008). The IAPV was discovered and purified in 2002 after the propagation extract of a bee taken from a group of dead bees, which became ill in the vicinity of Alon Hagalil, Israel (SHEN et al., 2005; RIBIĖRE et al, 2008; De MIRANDA et al., 2010). The ABPV and KBV can also infect different species of bees (BAILEY \& BALL, 1991), among them Africanized bees. In Brazil, the ABPV viruses have been detected in apiaries in Tocantins, Minas Gerais, and São Paulo, and the IAPV virus has been detected in São Paulo (MESSAGE et al., 1996; TEIXEIRA et al., 2008a, 2008b; TEIXEIRA et al., 2012; MESSAGE et al., 2012).

\section{Chronic Bee Paralysis Virus (CBPV)}

The CBPV manifests in adult bees through two distinct sets of symptoms and includes visible modifications in the behavior of bees (BAILEY \& BALL, 1991). Symptoms initially consist of fluttering of the wings and body, clusters of non-flying bees that typically crawl at the entrance to the hive, and a swollen abdomen, which triggers the onset of so-called “dysentery" (BAILEY \& BALL, 1991; RUBIÈRE et al., 2009; De MIRANDA et al, 2013; McMAHON et al., 2018). In addition, bees are blackish and hairless (RUBIÈRE et al., 2009). The virus is transmitted efficiently through contact and feeding, and can be detected in fecal material. The insects die a few days after the infection (RUBIĖRE et al., 2009; De MIRANDA et al., 2013). The virus is detected in sporadic outbreaks during the year, suggesting that it may remain in some individuals in low titers and with no visible symptoms (RIBIÈRE et al., 2008).

\section{Sacbrood virus (SBV)}

SBV reaches larvae that have a light-yellow coloration and the heads raised to the opening of the operculum, forming a kind of a bag that contains liquid. It has also been identified in adult bees. In adults, the virus can accumulate in the brain, especially in drones, but without visible symptoms (De MIRANDA et al., 2013). Most infected forage bees do not collect pollen, and those that do contaminate the pollen with the virus, contributing to shortening the life of worker bees and larvae that ingest the contaminated food, due to the accumulation of the virus in the hypothermic glands of bees (BAILEY \& BALL, 1991). MONDET et al. (2014) reported the positive association of $V$. destructor in SBV transmission. According to GISDER \& GENERSCH (2017), SBV appears to be more associated with $A$. mellifera bees; although, it has been identified in some non-apis species (SINGH et al., 2010), including B. atratus in Argentina REYNALDI et al., 2013). SBV has been reported in Africanized honeybee hives in southern and southeastern Brazil (FREIBERG et al., 2012).

\section{Ectoparasites often associated with viral transmission Varroa destructor}

This ectoparasite is considered one of the main threats to apiculture in the world, and causes economic damages and losses (BOECKING \& GENERSCH, 2008). It is related to the patterns of Colony Collapse Disorder, suppresses the immune system of bees, is associated with the virulence of many viruses (DWV and APV, for example), and is an important factor of viral transmission within and between colonies. The Varroa cycle is composed of two distinct stages: forethic and reproductive. During the forethic phase, the mite feeds on the hemolymph of adult bees and can be transmitted within and between colonies (FORFET, 2016). To complete its cycle, invasion of larval cells of the bee often occurs (hornet cells can be preferentially invaded), with reproduction in cells of developing workers (BOECKING \& GENERSCH, 2008). Feeding on hemolymph causes damage that includes impaired learning ability, which can affect the ability of worker bees to navigate and return to the hive (BOECKING \& GENERSCH, 2008; FORFET, 2016). Some viruses have already been detected in Varroa, characterizing the mite as a carrier of infections that harm the health of bees, such as DWV and BQCV viruses (NEUMANN \& CARRECK, 2010). This ectoparasite is not exclusive to European bees. In Brazil, it is present in other bee species, such as A. mellifera scutellata and Africanized bees (ROSENKRANZ, 1999; LOCKE, 2015).

The natural host of the mite is the Asian bee (A. cerana). It is restricted to the brood of 
hornets, because when it enters the litter of the pupae of worker bees it is removed by adult bees in the course of their hygienic behavior (LOCKE, 2015). Specific removal of the mite is termed Varroa sensitive hygiene (PANZIERA et al., 2017). European bees have behavioral defenses similar to those of Asian bees, such as grooming and hygienic behavior (LOCKE et al., 2015). However, this behavior may be less pronounced and efficient in European bees when compared to that in other species, such as African and Africanized bees (GRAMACHO, 1999; FRIES et al., 1996; LOCKE et al., 2015).

The mite was first reported in Brazil in Africanized bees in 1970. Initially it represented a threat due to its high rate of infestation. However, with time a reduction in infestation was observed, suggesting an adaptive process of the bees (GRAMACHO, 1991). Africanized bees do not require control of mites because they can keep infestation rates low, suggesting their resistance to $V$. destructor. Studies are underway to understand the relationship of Varroa parasitism to bees and its association with other pathogens (LOCKE et al., 2015; PANZIERA et al., 2017).

\section{Nosema spp.}

$N$. apis and $N$. ceranae are obligate intracellular parasites of the intestinal cells. They are responsible for Nosemosis. They cause pathological changes of the digestive tract and impair the digestion and absorption of nutrients, leading to malnutrition and premature death of bees. These agents affect the health of colonies, especially in temperate regions, where Nosema spp. do not induce symptoms at low or medium levels of infection (POHORECKA et al., 2018). Epidemiological surveys of Nosema spp. performed in South America detected $N$. ceranae (MAGGI et al., 2016), which had been reported in Brazil since 1979 (TEIXEIRA et al., 2008b). Both parasites are associated with BQCV and Bee viruses Y (BVY) viruses (BAILEY \& BALL, 1991).

\section{CONCLUSION}

Viruses affect the health of bees and contribute to colony loss. In Brazil, some of these viruses have already been identified. These include DWV, ABPV, BQCV, IAPV, SBV, and VDV-1. Understanding the role of the pathogen in hosts will lead to the discovery of new viruses as well as clarifying the routes used for transmission, association with other parasites, disease symptoms, and the development of prevention strategies.

\section{DECLARATION OF CONFLICT OF INTERESTS}

The authors declare no conflict of interest.

\section{ACKNOWLEDGEMENTS}

FL Monteiro was the recipient of a PNPD/CAPES fellowship (Programa Nacional de Pós-Doutorado/Coordenação de Aperfeiçoamento de Pessoal de Nível Superior).

\section{AUTHORS' CONTRIBUTIONS}

All authors contributed equally for the conception and writing of the manuscript. All authors critically revised the manuscript and approved of the final version.

\section{REFERENCES}

AMOSCIA, et al. Haemolymph removal by the parasite Varroa destructor can trigger the proliferation of the Deformed Wing Virus in mite infested bees (Apis mellifera), contributing to enhanced pathogen virulence. BioRxiv, 2018. Available from: $<$ https://www. biorxiv.org/content/10.1101/257667v1>. Accessed: Jan. 9, 2019. doi: $10.1101 / 257667$.

BAILEY, L.; BALL, B. V. Honeybee pathology. In: Academic Press Books, London, United Kingdom, $2^{\mathrm{a}}$ ed., 1991.

BIGOT, D. et al. The discovery of Halictivirus resolves the Sinaivirus phylogeny. Journal of General Virology, v.98, p.2864-2875, 2017. Available from: <https://www.ncbi.nlm.nih. gov/pubmed/29058655>. Accessed: Feb. 5, 2019. doi: 10.1099/ jgv.0.000957.

BOECKING, O. GENERSCH, E. Varroosis - the Ongoing Crisis in Bee Keeping. Journal für Verbraucherschutz und Lebensmittelsicherheit, v.3, n2, p.221-228, 2008. Available from: $<$ https://link.springer.com/article/10.1007/s00003-008-0331-y>. Accessed: Jan. 10, 2019. doi: 10.1007/s00003-008-0331-y.

CHEN, Y. et al. Horizontal and vertical transmission of viruses in the honey bee, Apis mellifera. Journal of Invertebrate Pathology, v.92, n3, p.152-159, 2006. Available from: <https:// www.sciencedirect.com/science/article/pii/S0022201106000814>. Accessed: Dec. 13, 2018. doi: 10.1016/j.jip.2006.03.010.

COULON, M. et al. Metabolization of thiamethoxam (a neonicotinoid pesticide) and interaction with the Chronic bee paralysis virus in honeybees. Pesticide Biochemistry and Physiology, v.144, p.10-18, 2018. Available from: <https://www. ncbi.nlm.nih.gov/pubmed/29463403>. Accessed: Jan. 10, 2019. doi: 10.1016/j.pestbp.2017.10.009.

DeGRANDI-HOFFMAN, G.; CHEN, Y. Nutrition, immunity and viral infections in honey bees. Current Opinion in Insect Science, v.10, p.170-176, 2015. Available from: <https://www. sciencedirect.com/science/article/pii/S2214574515000863>. Accessed: Dec. 13, 2018. doi: 10.1016/j.cois.2015.05.007.

De MIRANDA, J. R.; GENERSCH, E. Deformed wing virus. Journal of Invertebrate Pathology, v.103, p.48-61, 2010. Available from: <https:/www.ncbi.nlm.nih.gov/pubmed/19909976>. Accessed: Dec. 14, 2018. doi: 10.1016/j.jip.2009.06.012. 
De MIRANDA, J. R. et al. Standard methods for virus research in Apis mellifera. Journal of Apicultural Research, v. 52, n. 4, 2013. Available from: <https://www.tandfonline.com/doi/ abs/10.3896/IBRA.1.52.4.22>. Accessed: Jan. 21, 2019. doi: 10.3896/IBRA.1.52.4.22.

De MIRANDA J. R. et al. Genome characterization, prevalence and distribution of a macula-like virus from Apis mellifera and Varroa destructor. Viruses, v.7, p.3586-3602, 2015. Available from: $<$ https://www.ncbi.nlm.nih.gov/pmc/articles/PMC4517118/>. Accessed: Jan. 24, 2019. doi:10.3390/v7072789.

FORFET, N. et al. Viral prevalence increases with regional colony abundance in honey bee drones (Apis mellifera L.). Infection, Genetics and Evolution, v. 44, p.549-554, 2016. Available from: $<$ https://www.ncbi.nlm.nih.gov/pubmed/27444641>. Accessed: Dec. 13, 2018. doi: 10.1016/j.meegid.2016.07.017.

FREIBERG, M. et al. First report of sacbrood virus in honey bee (Apis mellifera) colonies in Brazil. Genetics and Molecular Research, v.11, n.3, p.3310-3314, 2012. Available from: <https:// www.ncbi.nlm.nih.gov/pubmed/23079825>. Accessed: Sep. 17, 2018. doi: 10.4238/2012.September.12.14.

FRIES, I. et al. Nosema ceranae (Microspora, Nosematidae), morphological and molecular characterization of a microsporidian parasite of the Asian honey bee Apiscerana (Hymenoptera, Apidae). European Journal of Protistology, v.32, p.356-365, 1996. Available from: <https://www.sciencedirect.com/science/ article/pii/S0932473996800599>. Accessed: Dec. 14, 2018. doi: 10.1016/S0932-4739(96)80059-9.

GENERSCH, E. Honey bee pathology: current threats to honey bees and beekeeping. Applied Microbiology and Biotechnology, v.87, n.1, p.87-97, 2010. Available from: <https://www.ncbi. nlm.nih.gov/pubmed/20401479>. Accessed: Mar. 17, 2018. doi: $10.1007 / \mathrm{s} 00253-010-2573-8$.

GENERSCH, E. et al. Detection of deformed wing virus, a honey bee viral pathogen, in bumble bees (Bombus terrestris and Bombus pascuorum). Journal of Invertebrate Pathology, v.91, p.61-63, 2006. Available from: <https:/www.ncbi.nlm.nih.gov/ pubmed/16300785>. Accessed: Jan. 11, 2019. doi: 10.1016/j. jip.2005.10.002.

GIANNINI, T. C. et al. The dependence of crops for pollinators and the economic value of pollination in Brazil. Journal of Economic Entomology, v.108, p.109, 2015. Available from: <https://www. ncbi.nlm.nih.gov/pubmed/26470203>. Accessed: Jan. 21, 2018. doi: $10.1093 /$ jee/tov093.

GISDER, S.; GENERSCH, E. Viruses of commercialized insect pollinators. Journal of Invertebrate Pathology, v.147, p.51-59, 2017. Available from: <https://www.ncbi.nlm.nih.gov/pubmed/27498219>. Accessed: Mar. 17, 2018. doi: 10.1016/j.jip.2016.07.010.

GRAMACHO, K. P. et al. Influence of body fluid from pinkilled honey bee pupae on hygienic behavior. Apidologie, v.30, p.367-374, 1999. Available from: <https://www.apidologie.org/ articles/apido/abs/1999/04/Apidologie_0044-8435_1999_30_5_ ART0002/Apidologie_0044-8435_1999_30_5_ART̄0002.html $>$. Accessed: Jan. 10, 2018. doi: 10.1051/apido: $\overline{1} 9 \overline{9} 90502$.

LEVIN, S. et al. Presence of Apis Rhabdovirus-1 in populations of pollinators and their parasites from two continents. Frontiers in Microbiology, v.8, p.2482, 2017. Available from: $<$ https://www. ncbi.nlm.nih.gov/pubmed/29312191>. Accessed: Jan. 9, 2019. doi: 10.3389/fmicb.2017.02482.

LEVITT, A. L. et al. Cross-species transmission of honey bee viruses in associated arthropods. Virus Research, v.176, p.232-240, 2013. Available from: <https://www.ncbi.nlm.nih.gov/pubmed/23845302>. Accessed: Feb. 5, 2018. doi: 10.1016/j.virusres.2013.06.013.

LI, J. L. et al. Systemic spread and propagation of a plantpathogenic virus in European honeybees, Apis mellifera. MBio, v.5, p.e00898-00813, 2014. Available from: $<$ https://mbio.asm.org/ content/5/1/e00898-13>. Accessed: Jan. 24, 2019. doi: 10.1128/ mBio.00898-13.

LOCKE, B. et al. Natural Varroa mite-surviving Apis mellifera honeybee populations. Apidologie, v.47, p.467-482, 2015. Available from: <https://link.springer.com/article/10.1007/s13592-015-04128>. Accessed: Jan. 24, 2019. doi: 1007/s13592 -015-0412-8.

MAGGI, M. et al. Honeybee health in South America. Apidologie, v.47, p.835-85, 2016. Available from: <https://link.springer.com/ article/10.1007/s13592-016-0445-7>. Accessed: Mar. 17, 2018. doi: 10.1007/s13592-016-0445-7.

McMAHON, et al. Emerging Viruses in Bees: From Molecules to Ecology. Advances in Virus Research, v.20, p.251-291, 2018. Available from: <https://www.sciencedirect.com/science/article/ pii/S0065352718300113>. Accessed: Mar. 17, 2018. doi: 10.1016/ bs.aivir.2018.02.008.

McMENAMIN, A.; FLENNKEN, M. Recently identified bee viruses and their impact on bee pollinators. Current Opinion in Insect Science, v.26, p.120-129, 2018. Available from: <https:// www.sciencedirect.com/science/article/pii/S2214574517300755>. Accessed: Jan. 21, 2018. doi: 10.1016/j.cois.2018.02.009.

McMENAMIN, A. J.; GENERSCH, E. Honey bee colony losses and associated viruses. Current Opinion in Insect Science, v.8, p.121-129, 2015. Available from: <https://www.sciencedirect. com/science/article/pii/S2214574515000188>. Accessed: Feb. 5, 2018. doi: $10.1016 /$ j.cois.2015.01.015.

MESSAGE, D. et al. Situação da Sanidade das Abelhas no Brasil. In: IMPERATRIZ-FONSECA et al. Polinizadores no Brasil: contribuição e perspectivas para a biodiversidade, uso sustentável, conservação e serviços ambientais. São Paulo: Editora da Universidade de São Paulo, 237-256, 2012.

MOLINERI, A. et al. Risk factors for the presence of deformed wing virus and acute paralysis virus under temperate and subtropical climate in Argentinian bee colonies. Preventive Veterinary Medicine, v.140, p.106-115, 2017. Available from: $<$ https://www.ncbi.nlm.nih.gov/pubmed/28460743>. Accessed: Dec. 14, 2018. doi: 10.1016/j.prevetmed.2017.02.019.

MORDECAI, G. J. et al. Moku virus; a new Iflavirus found in wasps, honey bees and Varroa. Scientific Reports, v.6, p.34983, 2016. Available from: <https://www.nature.com/articles/srep34983>. Accessed: Dec. 14, 2018. doi: 10.1038/srep3498.

NAZZI, F.; PENACCHIO, F. Honey Bee Antiviral Immune Barriers as Affected by Multiple Stress Factors: A Novel Paradigm to Interpret Colony Health Decline and Collapse. Viruses, v.10, p.159, 2018. Available from: <https://www.ncbi. nlm.nih.gov/pubmed/29601473>. Accessed: Jan. 11, 2019. doi:10.3390/v10040159. 
NEUMANN, P.; CARRECK, N. L. Honey bee colony losses. Journal of Apicultural Research, v.49, p.1-6, 2010. Available from: $<$ https:// www.researchgate.net/publication/228361576_Honey_bee_colony_ losses>. Accessed: Sep. 22, 2018. doi: 10.3896/IBRA.1.49.1.01.

PANZIERA, D. et al. Varroa sensitive hygiene contributes to naturally selected varroa resistance in honey bees. Journal of Apicultural Research, v.56, n.5, p.635-642, 2017. Available from: <https://www.tandfonline.com/doi/full/10.10 80/00218839.2017.1351860>. Accessed: Dec. 13, 2018. doi: $10.1080 / 00218839.2017 .1351860$

PENG, W. et al. Host range expansion of honey bee black queen cell virus in the bumble bee, Bombus huntii. Apidologie, v.42, p.650-658, 2011. Available from: <https://link.springer.com/ article/10.1007/s13592-011-0061-5>. Accessed: Sep. 22, 2018. doi: $10.1007 / \mathrm{s} 13592-011-0061-5$.

PETTIS, J.S. et al. Crop pollination exposes honey bees to pesticides which alters their susceptibility to the gut pathogen Nosema ceranae. PLoS One, v.8, p.70182, 2013. Available from: <https://journals. plos.org/plosone/article?id=10.1371/journal.pone.0070182>. Accessed: Dec. 14, 2018. doi: 10.1371/journal.pone.0070182.

POHORECKA, et al. The spring assessment of Nosema Spp. Infection in Honey Bee Colonies (Apis mellifera L.) - Sampling as an Important Aspect of a Reliable Diagnosis. Journal of Apicultural Science, v.62, n.1, p.61-66, 2018. Available from: $<$ https://content.sciendo.com/view/journals/jas/62/1/article-p61. xml>. Accessed: Sep. 22, 2018. doi: 10.2478/jas-2018-0007.

TEIXEIRA, E.W. et al. Virus infection in Brazilian honey bees. Journal of Invertebrate Pathology, v.99, p.117-119, 2008a Available from: <https://www.sciencedirect.com/science/article/ pii/S0022201108000785>. Accessed: Feb. 5. 2018. doi: 10.1016/j. jip.2008.03.014.

TEIXEIRA, E. W. et al. First metagenomic analysis of microorganisms in honey bees from Brazil. Boletim da Indústria Animal, v.65, p.355-361, 2008b. Available from: <http://agris.fao.org/agris-search/ search.do?recordID=BR2015F01671>. Accessed: Feb. 5, 2018.

TEIXEIRA, E. W. et al. Israeli acute paralysis virus in Africanized honey bees in southeastern Brazilian apiaries. Journal of Apicultural Research, v.51, p.282-284, 2012. Available from: $<$ https://www.tandfonline.com/doi/abs/10.3896/IBRA.1.51.3.11>. Accessed: Feb. 5, 2018. doi: 10.3896/ IBRA.1.51.3.11.

RADZEVIČIŪTĖ, R. et al. Replication of honey bee-associated RNA viruses across multiple bee species in apple orchards of Georgia, Germany and Kyrgyzstan. Journal of Invertebrate Pathology, v.146, p.14-23, 2017. Available from: $<$ https://www. ncbi.nlm.nih.gov/pubmed/28392285>. Accessed: Dec. 22, 2018. doi: 10.1016/j.jip.2017.04.002.

REMNANT, E. et al. A Diverse Range of Novel RNA Viruses in Geographically Distinct Honey Bee Populations. Journal of Virology, v.91, p.e00158-17, 2017. Available from: <https://www. ncbi.nlm.nih.gov/pubmed/28515299>. Accessed: Dec. 14, 2018. doi: $10.1128 /$ JVI.00158-17.

RIBIÈRE, M. et al. Natural history and geographical distribution of honey bee viruses. In AUBERT, M. et al. Virology and the honey bee. Luxembourg: EEC Publications, p.19-25, 2008.
ROSENKRANZ, P. Honey bee (Apis mellifera L.) tolerance to Varroa jacobsoni Oud. in South America. Apidologie, v.30, p.159-172, 1999. Available from: <https:/www.apidologie.org/ articles/apido/abs/1999/02/Apidologie_0044-8435_1999 30_2-3 ART0006/Apidologie 0044-8435 $1999 \quad 30 \quad$ 2-3 ART0006. html>. Accessed: Feb. 5, 2018. doi: 10.1051/apido:19990206.

RUNCKEL, C. et al. Temporal analysis of the honey bee microbiome reveals four novel viruses and seasonal prevalence of known viruses, Nosema, and Crithidia. PLoS One, v.6, p.e20656, 2011. Available from: <https:/www.ncbi.nlm.nih. gov/pubmed/21687739>. Accessed: Sep. 22, 2018. doi: 10.1371/ journal.pone.0020656.

SANTAMARIA, J. et al. Evidence of Varroa-mediated deformed wing virus spillover in Hawaii. Journal of Invertebrate Pathology, v.151, p.126-130, 2018. Available from: <https:// www.ncbi.nlm.nih.gov/pubmed/29175033>. Accessed: Dec. 14, 2018. doi: 10.1016/j.jip.2017.11.008

SHEN, M. et al. Intricate transmission routes and interactions between picorna-like viruses (Kashmir bee virus and sacbrood virus) with the honeybee host and the parasitic Varroa mite. Journal of General Virology, v.86, p.2281-2289, 2005. Available from: $<$ https://www.ncbi.nlm.nih.gov/pubmed/16033976>. Accessed: Sep. 22, 2018. doi: 10.1099/vir.0.80824-0.

SINGH, R. et al. RNA viruses in hymenopteran pollinators: evidence of inter-taxa virus transmission via pollen and potential impact on non-apis hymenopteran species. PLoS One, v.5, p.e14357, 2010. Available from: <https://journals.plos.org/ plosone/article?id=10.1371/journal.pone.0014357>. Accessed: Dec. 14, 2018. doi: 10.1371/journal.pone.0014357.

VANDAME, R. et al. Parasitism in the social bee Apis mellifera: quantifying costs and benefits of behavioral resistance to Varroa destructor mites. Apidologie, v.33, p.433-445, 2002. Available from: $<$ https://www.apidologie.org/articles/apido/abs/2002/05/02/02. html >. Accessed: Dec. 14, 2018. doi: 10.1051/apido:2002025.

VANDAME, R.; PALACIO, M.A. Preserved honey bee health in Latin America: a fragile equilibrium due to low-intensity agriculture and beekeeping? Apidologie, v.41, p.243-255, 2010. Available from: <https://www.apidologie.org/articles/apido/full html/2010/03/m09133/m09133.html>. Accessed: Jan. 9, 2019. doi: 10.1051/apido/2010025

ZHANG, $X$. et al. New evidence that deformed wing virus and black queen cell virus are multi-host pathogens. Journal of Invertebrate Pathology, v.109, p.156-159, 2012. Available from: $<$ https://www.ncbi.nlm.nih.gov/pubmed/22001629>. Accessed: Oct. 18, 2018. doi: 10.1016/j.jip.2011.09.010.

YUE, C. et al. Vertical-transmission routes for deformed wing virus of honeybees (Apis mellifera). Journal of General Virology, v.88, p.2329-2336, 2007. Available from: <https://www.ncbi. nlm.nih.gov/pubmed/17622639>. Accessed: Sep. 22, 2018. doi: 10.1099/vir.0.83101-0

YUE, C.; GENERSH, E. RT-PCR analysis of deformed wing virus in honeybees (Apis mellifera) and mites (Varroa destructor). Journal of General Virology, v.86, p.3419-3424, 2015. Available from: $<\mathrm{https} / /$ www.ncbi.nlm.nih.gov/pubmed/16298989>. Accessed: Feb. 5, 2018. doi:10.1099/vir.0.81401-0. 